\title{
Digitizing "The NBS Tables of Chemical Thermodynamic Properties: Selected Values for Inorganic and C1 and C2 Organic Substances in SI Units"1
}

\author{
Janiel J. Reed \\ National Institute of Standards and Technology, \\ Gaithersburg, MD 20899, USA \\ janiel.reed@nist.gov \\ Data DOI: https://doi.org/10.18434/M32124 \\ Key words: chemical thermodynamics; enthalpy; entropy; evaluated data; Gibbs energy; inorganic chemistry; NBS Tables; \\ thermochemistry.
}

Accepted: January 14, 2020

Published: February 4, 2020

https://doi.org/10.6028/jres.125.007

\section{Summary}

The NBS Tables of Chemical Thermodynamic Properties [1] is a collection of thermodynamic properties, published in book form, consisting of 103 tables with 14330 critically evaluated species. The tables were originally published as a series of NBS $^{2}$ Technical Notes [2]. As a result of this work, the data is now available in a more accessible spreadsheet format. Enthalpy of formation, $\Delta_{\mathrm{f}} \mathrm{H}^{\circ}$, Gibbs energy of formation, $\Delta_{\mathrm{f}} \mathrm{G}^{\circ}$, entropy, $\mathrm{S}^{\circ}$, heat capacity at constant pressure, $\mathrm{C}_{\mathrm{p}}^{\circ}$, all at $298.15 \mathrm{~K}$, and the enthalpy difference, $\left[\mathrm{H}^{\circ}(298)-\mathrm{H}^{\circ}(0)\right]$ are provided where known. Within this collection of data, there are no values given for transuranic elements, Np to Lr (Tables 77-87).

\footnotetext{
${ }^{1}$ Certain software products are identified in this paper in order to specify the procedure adequately. Such identification is not intended to imply recommendation or endorsement by NIST, nor is it intended to imply that the products identified are necessarily the best available for the purpose.

${ }^{2}$ National Bureau of Standards, now NIST, National Institute of Standards and Technology.
} 


\section{Data Specifications}

\begin{tabular}{ll}
\hline NIST Operating Unit(s) & $\begin{array}{l}\text { Material Measurement Laboratory, Chemical Sciences Division, } \\
\text { Chemical Informatics Research Group }\end{array}$ \\
\hline Format & CSV, Excel \\
\hline Accessibility & $\begin{array}{l}\text { All datasets submitted to Journal of Research of NIST are publicly } \\
\text { available. }\end{array}$ \\
\hline License & https://www.nist.gov/director/licensing \\
\hline
\end{tabular}

\section{Methods}

The NBS Tables of Chemical Thermodynamic Properties [1] book was digitized (optical character recognition - OCR) into a portable document format (PDF) file. The tables within the PDF file were copied (Fig. 1) and pasted into Microsoft Word (Fig. 2). Within Word, column alignments and chemical formulas were fixed using the PDF as a guide. From Word, the data were then copied into Excel and printed. Using the original book as a guide, all tables were manually edited and corrected. After editing, the contents of the spreadsheet were checked using a Python script. State identifiers were checked for consistency and numeric values were checked for format and range. An erratum [4] was used to include corrected values in the data which is indicated with an asterisk. Due to the small amount of values from the erratum [4], they were checked manually.

Figure 1 below shows the digitized results of a section of the Tables for terbium and Fig. 2 shows the same content after it has been copied into Microsoft Word.

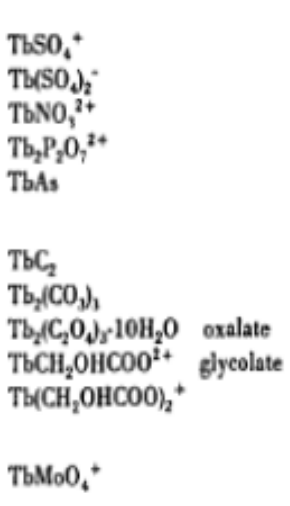

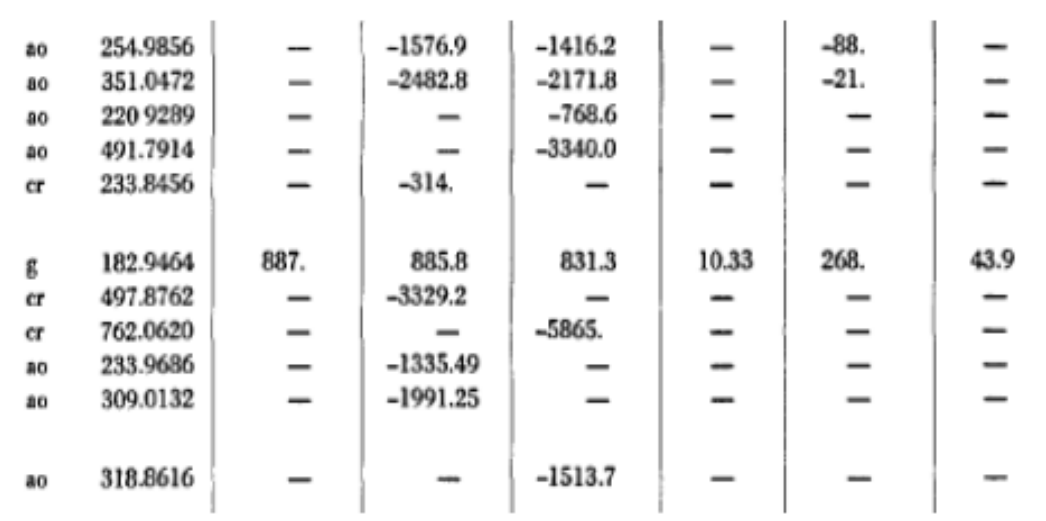

Fig. 1. A section of the Tables copied from the original PDF file. 


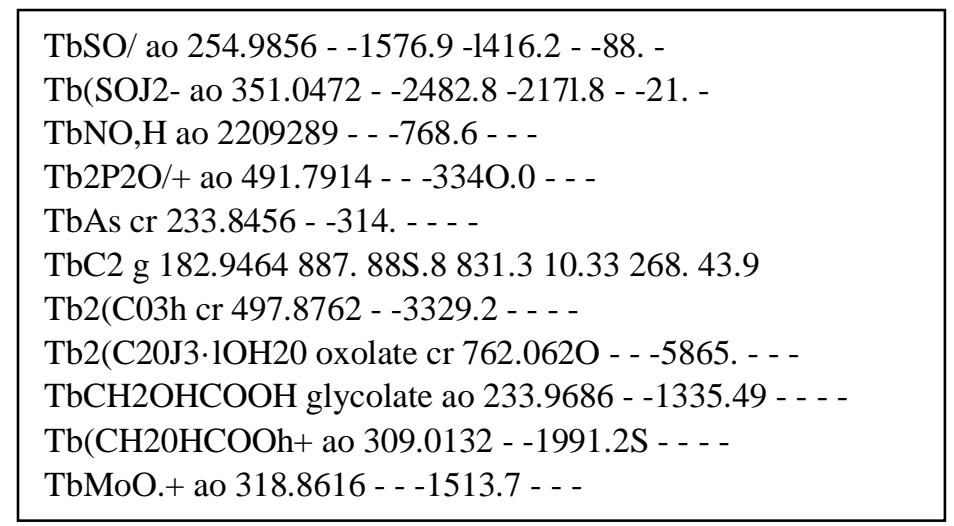

Fig. 2. The same section of the Tables in Fig. 1, shown here as it appears when copied from the PDF file into an MS Word file.

The methods used to compile and evaluate the data are provided in chapters two through six of Ref. [1]. Table 1 describes each column in the Excel file.

Table 1. Description of each column in the Excel file.

\begin{tabular}{|l|l|}
\hline Heading & Description \\
\hline Formula & Written in conventional manner \\
\hline Solvent & $\begin{array}{l}\text { Physical state that is normal for the indicated solvent at 298.15 K (almost } \\
\text { always liquid). May be a mixture }\end{array}$ \\
\hline Name & Name of given formula \\
\hline State Description & Additional information about the state of the species \\
\hline State & $\begin{array}{l}\text { Physical state of each substance is indicated as crystalline solid (cr), liquid } \\
\text { (l), vitreous or glassy (vit), amorphous (am), or gaseous }(\mathrm{g})\end{array}$ \\
\hline Molar Mass $\left(\mathrm{g} \mathrm{mol}^{-1}\right)$ & Molar mass in gram per mole of substance \\
\hline $0 \mathrm{~K} \Delta_{\mathrm{f}} \mathrm{H}^{\circ}\left(\mathrm{kJ} \mathrm{mol}^{-1}\right)$ & Enthalpy of formation at $0 \mathrm{~K}$ \\
\hline$\Delta_{\mathrm{f}} \mathrm{H}^{\circ}\left(\mathrm{kJ} \mathrm{mol}^{-1}\right)$ & Enthalpy of formation at $298.15 \mathrm{~K}$ and 1 bar \\
\hline$\Delta_{\mathrm{f}} \mathrm{G}^{\circ}\left(\mathrm{kJ} \mathrm{mol}^{-1}\right)$ & Gibbs energy of formation \\
\hline $\mathrm{H}^{\circ}-\mathrm{H}_{0}^{\circ}\left(\mathrm{kJ} \mathrm{mol}^{-1}\right)$ & Enthalpy difference \\
\hline $\mathrm{S}^{\circ}\left(\mathrm{J} \mathrm{mol}^{-1} \mathrm{~K}^{-1}\right)$ & Molar entropy \\
\hline $\mathrm{C}_{\mathrm{p}}\left(\mathrm{J} \mathrm{mol}^{-1} \mathrm{~K}^{-1}\right)$ & Heat capacity at constant pressure \\
\hline
\end{tabular}

The break between the tables consist of two rows. The first row contains the table number followed by the element symbol. The second row contains the full name of the element and the year it was prepared.

\section{Impact}

The NBS Tables of Chemical Thermodynamic Properties [1] is one of the most highly cited works in the history of NBS/NIST and is still used and cited in the academic, scientific, and engineering areas. In compliance with the Open Government Data Act [3], which "requires open government data assets to be published as machine-readable data,” the NBS Tables are now accessible through CSV and Excel formats at https://doi.org/10.18434/M32124. 


\section{References}

[1] Wagman DD, Evans WH, Parker VB, Schumm RH, Halow I, Bailey SM, Churney KL, Nuttall RL (1982) The NBS tables of chemical thermodynamic properties. Selected values for inorganic and $\mathrm{C}_{1}$ and $\mathrm{C}_{2}$ organic substances in SI units. Journal of Physical and Chemical Reference Data 11:2. Available at https://srd.nist.gov/JPCRD/jpcrdS2Vol11.pdf

[2] Wagman DD, Evans WH, Parker VB, Halow I, Bailey SM, Schumm RH, Churney KL, Nuttall RL (1968-1981) Selected values of chemical thermodynamic properties. (National Bureau of Standards, Gaithersburg, MD), NBS Technical Note 270 Parts 3-8. https://doi.org/10.6028/NBS.TN.270-3, https://doi.org/10.6028/NBS.TN.270-4, https://doi.org/10.6028/NBS.TN.270-5, https://doi.org/10.6028/NBS.TN.270-6, https://doi.org/10.6028/NBS.TN.270-7, https://doi.org/10.6028/NBS.TN.270-8

[3] Foundations for Evidence-Based Policymaking Act, Public Law No. 115-435 (2018) Available at https://www.congress.gov/bill/115th-congress/house-bill/4174

[4] Wagman DD, Evans WH, Parker VB, Schumm RH, Halow I, Bailey SM, Churney KL, Nuttall RL (1989) Erratum: The NBS tables of chemical thermodynamic properties. Selected values for inorganic and C1 and C2 organic substances in SI units [J. Phys. Chem. Ref. Data 11, Suppl. 2 (1982)]. Journal of Physical and Chemical Reference Data 18(4):1807-1812. https://doi.org/10.1063/1.555845

About the author: Janiel J. Reed is an IT Specialist (System Analysis) in the Chemical Sciences Division in the Materials Measurement Laboratory. The National Institute of Standards and Technology is a bureau of the U.S. Department of Commerce. 